\title{
Socioeconomic Impacts of Microfinance Programs in the Development of Bangladesh
}

\author{
Rezaul Karim ${ }^{1}$ \\ ${ }^{1}$ Department of Business Administration, Atish Dipankar University of Science and Technology, Dhaka, \\ Bangladesh \\ Correspondence: Department of Business Administration, Atish Dipankar University of Science and Technology, \\ Dhaka, Bangladesh, E-mail: rezaul.karim00@ gmail.com
}

Received: June 21, 2017

Accepted: July 15, 2017

Online Published: July 25, 2017

\begin{abstract}
The study was conducted to find out what significant socioeconomic impact and how microfinance programs play the key role on the development of Bangladesh. To observe that we tried to find out in which way it is playing its role and what kind of socioeconomic impacts are related with microeconomic programs. Microfinance programs are providing a significant role in the development of Bangladesh by providing financial assistance to the lower income but self-employed people. They have turned into employed by getting the financial support from the different institutions especially from Grameen Bank, BRAC etc. The poverty level has minimized a lot from the rural area and household income increase by around one-third. Wages and marginal propensity to consumption (MPC) increased especially for women and it creates positive impact on children's schooling: A 1.05\% increase in Grameen Bank female borrowers increases the probability of school enrollment by $1.8 \%$ for girls and $1.99 \%$ for boys. Microfinance also contributed to smoothening consumption level and reducing vulnerability of life of people. It plays a role in eradicating poverty, promoting education, improving health and empowering women.
\end{abstract}

Keywords: GDP, NGO, MPC, Microfinance, Socioeconomic Impact.

\section{Introduction}

Schreiner and Colombet (2001, p.339) define microfinance as "the attempt to improve access to small deposits and small loans for poor households neglected by banks." Therefore, microfinance involves the provision of financial services such as savings, loans and insurance to poor people living in both urban and rural settings who are unable to obtain such services from the formal financial sector. According to Otero (1999, p.8) microfinance is "the provision of financial services to low-income poor and very poor self-employed people". These financial services according to Lidgerwood (1999) generally include savings and credit but can also include other financial services such as insurance and payment services. Micro credit and microfinance are relatively new terms in the field of development, first coming to prominence in the 1970s, according to Robinson (2001) and Otero (1999). Prior to then, from the 1950s through to the 1970s, the provision of financial services by donors or governments was mainly in the form of subsidized rural credit programmers. These often resulted in high loan 
defaults, high lose and an inability to reach poor rural households (Robinson, 2001). Robinson states that the 1980s represented a turning point in the history of microfinance in that MFIs such as Grameen Bank began to show that they could provide small loans and savings services profitably on a large scale. They received no continuing subsidies, were commercially funded and fully sustainable, and could attain wide outreach to clients (Robinson, 2001). It was also at this time that the term "micro credit" came to prominence in development (MIX, 2005). The 1990s "saw accelerated growth in the number of microfinance institutions created and an increased emphasis on reaching scale" (Robinson, 2001, p.54). Dichter (1999, p.12) refers to the 1990s as "the microfinance decade". Microfinance had now turned into an industry according to Robinson (2001). Along with the growth in micro credit institutions, attention changed from just the provision of credit to the poor (micro credit), to the provision of other financial services such as savings and pensions (microfinance) when it became clear that the poor had a demand for these other services (MIX, 2005). The importance of microfinance in the field of development was reinforced with the launch of the Micro credit Summit in 1997. The Summit aims to reach 175 million of the world's poorest families, especially the women of those families, with credit for the self-employed and other financial and business services, by the end of 20154 (Micro credit Summit, 2005). More recently, the UN, as previously stated, declared 2005 as the International Year of Micro credit.

\section{Literature Review}

Microfinance has a very important role to play in development according to proponents of microfinance. UNCDF (2004) states that studies have shown that microfinance plays three key roles in development. It:

- helps very poor households meet basic needs and protects against risks,

- is associated with improvements in household economic welfare,

- helps to empower women by supporting women's economic participation and promotes gender equity.

Otero (1999, p.10) illustrates the various ways in which "microfinance, at its core combats poverty". She states that microfinance creates access to productive capital for the poor, which together with human capital, addressed through education and training, and social capital, achieved through local organization building, enables people to move out of poverty. By providing material capital to a poor person, their sense of dignity is strengthened and this can help to empower the person to participate in the economy and society (Otero, 1999). The aim of microfinance according to Otero (1999) is not just about providing capital to the poor to combat poverty on an individual level, it also has a role at an institutional level. It seeks to create institutions that deliver financial services to the poor people, who are continuously ignored by the formal banking sector. Littlefield and Rosenberg (2004) state that the poor are generally excluded from the financial services sector of the economy, so MFIs have emerged to address this market failure. By addressing this gap in the market in a financially sustainable manner, an MFI can become part of the formal financial system of a country and so can access capital markets to fund their lending portfolios, allowing them to dramatically increase the number of poor people they can reach (Otero, 1999). More recently, commentators such as Littlefield, Murduch and Hashemi (2003), Simanowitz and Brody (2004) and the IMF (2005) have commented on the critical role of microfinance in achieving the Millennium Development Goals (MDG). Simanowitz and Brody (2004, p.1) state, "Microfinance is a key strategy in reaching the MDGs and in building global financial systems that meet the needs of the most poor people." Littlefield, Murduch and Hashemi (2003) state "microfinance is a critical contextual factor with strong impact on the achievements of the MDGs microfinance is unique among development interventions: it can deliver social benefits on an ongoing, permanent basis and on a large scale". Referring to various case studies, they show how microfinance has played a role in eradicating poverty, promoting education, improving health and empowering women (2003). However, not all commentators are as 
enthusiastic about the role of microfinance in development and it is important to realize that microfinance is not a silver bullet when it comes to fighting poverty. Hulme and Mosley (1996), while acknowledging the role microfinance can have in helping to reduce poverty, concluded from their research on microfinance that "most contemporary schemes are less effective than they might be" (1996, p.134). They state that microfinance is not a panacea for poverty-alleviation and that in some cases the poorest people have been made worse-off by microfinance. Rogaly (1996, p.109/110) finds five major faults with MFIs. He argues that:

- They encourage a single-sector approach to the allocation of resources to fight poverty,

- Micro credit is irrelevant to the poorest people,

- An over-simplistic notion of poverty is used,

- There is an over-emphasis on scale,

- There is inadequate learning and change taking place.

Wright (2000,p.6) states that much of the skepticism of MFIs stems from the argument that microfinance projects "fail to reach the poorest, generally have a limited effect on income...drive women into greater dependence on their husbands and fail to provide additional services desperately needed by the poor". In addition, Wright says that many development practitioners not only find microfinance inadequate, but that it actually diverts funding from "more pressing or important interventions" such as health and education (2000, p.6). As argued by Navajas et al (2000), there is a danger that microfinance may siphon funds from other projects that might help the poor more. They state that governments and donors should know whether the poor gain more from microfinance, than from more health care or food aid for example. Therefore, there is a need for all involved in microfinance and development to ascertain what exactly has been the impact of microfinance in combating poverty. Considerable debate remains about the effectiveness of microfinance as a tool for directly reducing poverty, and about the characteristics of the people it benefits (Chowdhury, Mosley and Simanowitz, 2004). Sinha (1998) argues that it is notoriously difficult to measure the impact of microfinance programs on poverty. This is so she argues, because money is fungible and therefore it is difficult to isolate credit impact, but also because the definition of 'poverty', how it is measured and who constitute the 'poor' 'are fiercely contested issues" (1998, p.3). Poverty is a complex issue and is difficult to define, as there are various dimensions to poverty. For some, such as World Bank, poverty relates to income, and poverty measures are based on the percentage of people living below a fixed amount of money, such as US\$1 dollar a day (World Bank, 2003).

3. Objectives of the Research

The objectives of the research include the following-

- To identify the key socioeconomic impacts of microfinance in Bangladesh.

- To find out in which way microfinance is playing the role in the development process of Bangladesh.

- To assess the impact to the livelihoods of project beneficiaries.

- To show what learning can be gained when socioeconomic impact assessments have a broad scope of analysis.

- To show some guidelines of the micro finance programs for more effective implementation in the development of Bangladesh.

\section{Methodology of the Research}

This research is a descriptive type of research that has undertaken insights and understanding about overall operation of socioeconomic development of Bangladesh and prepared on the basis of secondary sources. The secondary information was collected from different past files, which were collected from personal visit of the company files. 
5. A Brief Overview of NGOs-MFIs in Bangladesh

5.1 Sector Highlights

Table 1: Microfinance Industry in Bangladesh

\begin{tabular}{lll}
\hline 1 & Number of NGO-MFIs covered here & 425 \\
\hline 2 & Number of Branches & 11461 \\
\hline 3 & Total Employees & 104,327 \\
\hline
\end{tabular}

a) Male

87407

b) Female

16920

\begin{tabular}{|c|c|c|}
\hline 4 & Total Members (In millions) & 20.83 \\
\hline \multicolumn{2}{|c|}{ a) Male } & 3.06 \\
\hline \multicolumn{2}{|c|}{ b) Female } & 17.77 \\
\hline 5 & Total Borrowers (In millions) & 17.01 \\
\hline \multicolumn{2}{|c|}{ a) Male } & \\
\hline \multicolumn{2}{|c|}{ b) Female } & \\
\hline 6 & Total Savings (In million Taka) & 27759.38 \\
\hline 7 & Outstanding loan (In million Taka) & 85872.94 \\
\hline 8 & Average Savings per member (In Taka) & 1333 \\
\hline 9 & Average outstanding loan per borrower (In Taka) & 5048 \\
\hline 10 & Average Borrower to Member Ratio (In percentage) & $82 \%$ \\
\hline 11 & Average savings to outstanding loan ratio (In percentage) & $32 \%$ \\
\hline
\end{tabular}

The Microcredit Regulatory Authority (MRA) has classified of these 425 NGO-MFIs and their market share by categorizing as very small, small, medium, large, and very large on the basis of their number of borrowers, which are presented by the table. Besides these 425 institutions, there are more than 2500 tiny institutions which have either less than 1000 borrowers or less than Tk. 40 lacs (Tk. 4 million) loan outstanding. Among these 425 institutions, only 13 (3\% of 425) institutions actually occupy the major share of the market both in terms of loan outstanding $(81.47 \%)$ and savings collection $(76.35 \%)$, where in fact the largest two institutions have $65.93 \%$ and $57 \%$ share respectively. But it is noticeable that all institutions except very large two are having more market share in total savings than their share in total outstanding loan and 323 very small institutions have $6.49 \%$ of market share in savings collection where as they have only $4.36 \%$ share in loan outstanding. 
Table 2: NGOs-MFIs Classification Criteria

\begin{tabular}{|c|c|c|c|c|c|}
\hline \multicolumn{6}{|c|}{ Number of Institutions Under Different Categories } \\
\hline $\begin{array}{l}\text { Category } \\
\text { Borrower }\end{array}$ & of MFIs on the basis of & $\begin{array}{l}\text { No. of MFIs on } \\
\text { the basis of } \\
\text { borrowers }\end{array}$ & $\begin{array}{l}\% \text { of number } \\
\text { of MFIs }\end{array}$ & $\begin{array}{l}\% \text { of loan outstanding } \\
\text { (Principle) }\end{array}$ & $\%$ of total savings \\
\hline $\begin{array}{l}\text { Very } \\
\text { small }\end{array}$ & $<10,000$ & 323 & $76.00 \%$ & $4.36 \%$ & $6.49 \%$ \\
\hline Small & $\begin{array}{l}>\text { or }=10,000 \text { but } \\
<50,000\end{array}$ & 73 & $17.18 \%$ & $8.88 \%$ & $10.18 \%$ \\
\hline Medium & $\begin{array}{l}>\text { or }=50,000 \text { but } \\
<100,000\end{array}$ & 16 & $3.76 \%$ & $5.29 \%$ & $6.97 \%$ \\
\hline Large & $\begin{array}{l}>\text { or }=100,000 \text { but } \\
<1,000,000\end{array}$ & 11 & $2.59 \%$ & $15.54 \%$ & $19.19 \%$ \\
\hline $\begin{array}{l}\text { Very } \\
\text { Large }\end{array}$ & $>$ or $=1,000,000$ & 2 & $0.47 \%$ & $65.93 \%$ & $57.17 \%$ \\
\hline Total & & 425 & $100.00 \%$ & $100.00 \%$ & $100.00 \%$ \\
\hline
\end{tabular}

According to the MRA, although a number of organizations are rising fast, the MFIs sector is still dominated by a few institutions in Bangladesh. The MRA expects that there will be a good number of organizations which are going to in place to compete in the market and thus people will receive better services at a reasonable price in the near future. It seems to me that MRA's activities becoming impressive according to keep its promise and responses by presenting the NGOs-MFIs' overall picture, MRA's transparency regarding their monitoring aspects, ensuring their regular publicity and accountability according to the mandate.

\subsection{Sustainable Livelihood Framework in Impact Measurement}

We have seen that microfinance can have a wide range of impacts on households involved in the project, but also can have wider social impacts. There are different ways of measuring impact such as using Social Performance Assessments (SPAs), AIMS toolkit and Internal Learning Systems. Most assessments use quantitative research tools such as surveys, financial ratios and participatory tools, and qualitative tools such as focus group discussions and participant observation. This research is focused on the impact of microfinance on livelihood security. A livelihoods framework is people centered and aims to explain the relationships between people, their livelihoods, (macro) policies and all kinds of institutions. Brockets by and Fisher (2003, p.187) explain the four main components of the livelihoods framework, as used by DFID which has been widely adopted in the development field. These are:

- people live within a vulnerability context i.e. they are exposed to risks such as sudden shocks, trends over time and seasonal change;

- people have a number of capital assets which they draw upon to make their livelihoods;

- these assets are drawn upon within people's livelihood strategies;

- policies, institutions and processes help to shape people's assets, livelihood activities and the vulnerability context within which they live.

Carney (1998) states that an examination of the five capital assets offers a holistic analysis of people's 
livelihoods. These capital assets from the centerpiece of people's livelihoods as these assets dictate the level of vulnerability of beneficiaries to shocks and trends. Policies and institutions also have an impact on these assets. These policies and institutions, and beneficiaries' own vulnerability context influence their livelihood strategies which in turn dictate their livelihood outcomes as indicated in Figure.1 (ibid.). IDS (2004) also states that such a framework allows investigation into the ways in which a project directly and indirectly affects people's livelihoods. This framework therefore will be used in this study to assess the impact of microfinance on the beneficiaries' livelihoods by focusing on its impact on their five capital assets.

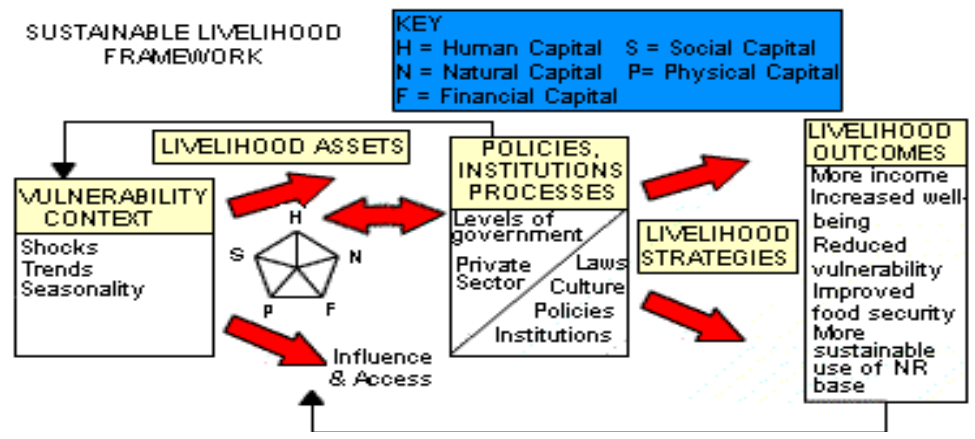

Fig. 1 Sustainable Livelihood Framework.

(Taken from DFID Sustainable Livelihoods Guidance Sheets, Section Two)

\section{Socioeconomic Impacts of Microfinance Programs}

The major socioeconomic impacts of microfinance programs are given below:

\subsection{Development Process}

Microfinance has a very important role to play in development according to proponents of microfinance. UNCDF (2004) states that studies have shown that microfinance plays three key roles in development. It:

- helps very poor households meet basic needs and protects against risks,

- $\quad$ is associated with improvements in household economic welfare,

- helps to empower women by supporting women's economic participation and so promotes gender equity.

There are various ways in which "microfinance, at its core combats poverty and microfinance creates access to productive capital for the poor, which together with human capital, addressed through education and training, and social capital, achieved through local organization building, enables people to move out of poverty. By providing material capital to a poor person, their sense of dignity is strengthened and this can help to empower the person to participate in the economy and society. The aim of microfinance is not just about providing capital to the poor to combat poverty on an individual level, it also has a role at an institutional level. It seeks to create institutions that deliver financial services to the poor, who are continuously ignored by the formal banking sector. Microfinance has the critical role of in achieving the Millennium Development Goals (MDG) in Bangladesh and it is a key strategy in reaching the MDGs and in building global financial systems that meet the needs of the poorest people. Referring to various case studies, they show how microfinance has played a role in eradicating poverty, promoting education, improving health and empowering women.

\subsection{Poverty Reduction}

Poverty is more than just a lack of income and the shortcomings of focusing solely on increased income as a measure of the impact of microfinance on poverty. There is a significant difference between increasing income and reducing poverty. By increasing the income of the poor, MFIs are not necessarily reducing poverty.It depends what the poor do with this money, oftentimes it is gambled away or spent on alcohol, so focusing solely 
on increasing incomes is not enough. The focus needs to be on helping the poor to "sustain a specified level of well-being" by offering them a variety of financial services tailored to their needs so that their net wealth and income security can be improved. Projects in India, Indonesia, Zimbabwe, Bangladesh and Uganda which all show very positive impacts of microfinance in reducing poverty. For instance, a report on a SHARE project in India showed that three-quarters of clients saw "significant improvements in their economic well-being and that half of the clients graduated out of poverty. There is clear evidence that the impact of a loan on a borrower's income is related to the level of income as those with higher incomes have a greater range of investment opportunities and so credit schemes are more likely to benefit the middle and upper poor. However, when MFIs such as the Grameen Bank and BRAC provided credit to very poor households, those households were able to raise their incomes and their assets. While microfinance has much potential the main effects on poverty have been:

- Credit making a significant contribution to increasing incomes of the better-off poor, including women,

- Microfinance services contributing to the smoothing out of peaks and troughs in income and expenditure thereby enabling the poor to cope with unpredictable shocks and emergencies.

\subsection{Livelihood Security}

Livelihood can be defined as comprising--the capabilities, assets (including both material and social resources) and activities required for a means of living. Livelihood security is "basic to well-being" and that security "refers to secure rights and reliable access to resources, food, income and basic services. It includes tangible and intangible assets to offset risk, ease shocks and meet contingencies." Livelihood security therefore, like poverty, is not just about income, but includes tangible and intangible assets, and social well-being. NGOs aiming for poverty reduction need to assess the impact of their services on user's livelihoods. In addressing the question of the impact of microfinance, NGOs must go beyond analyzing quantitative data detailing the numbers of users, and volumes and size of loans disbursed, to understanding how their projects are impacting on clients' livelihoods. The provision of microfinance can give poor people-the means to protect their livelihoods against shocks as well as to build up and diversify their livelihood activities. Therefore when analyzing the impact of microfinance the overall impact of the microfinance services on the livelihoods of the poor needs to be taken into consideration. That is the focus of this study.

\subsection{Social Impact}

We have seen that poverty and livelihood security consist of economic and social conditions, therefore, when analyzing the impact of microfinance, social impact must be assessed. The wider social impact assessment is important for an organization's internal learning process, as an MFI should be aware of the "full range of changes associated with its efforts and uses these to improve its performance". It needs to be considered that social impact to relate to human capital such as nutrition, health and education, as well as social networks. Impact must be assessed on each of these issues if a true picture of the impact of microfinance is to be obtained. Kabeer (2003, p.110) not only refers to domains of impact but also highlights dimensions of change that should be assessed. She lists cognitive change, behavioral change, material change, relational change and institutional change as dimensions of change that need to be taken into account if the wider effects of microfinance interventions are to be understood. Impact should be examined from cultural, economic, social and political domains at individual, enterprise and household levels. The wider social and economic impacts can occur through the labor market, the capital market, the market for goods consumed by poor people, through production linkages and through clients' participation in social and political processes. In the following sections I will 
examine the findings from wider assessments of microfinance interventions at a household and community level, to show what learning can be gained when impact assessments have a broad scope of analysis.

\subsection{Household Level Impacts}

Health and education are two key areas of non-financial impact of microfinance at a household level. Wright (2000, p.31) states that from the little research that has been conducted on the impact of microfinance interventions on health and education, nutritional indicators seem to improve where MFIs have been working. Research on the Grameen Bank shows that members are statistically more likely to use contraceptives than non-members, thereby impacting on family size. Some researches acknowledge the sparse specific evidence of the impact of microfinance on health but where studies have been conducted they conclude, "households of microfinance clients appear to have better nutrition, health practices and health education than comparable non-client households". Among the examples they give is of FOCCAS, a Ugandan MFI whose clients were given health care instructions on breastfeeding and family planning. They were seen to have much better health care practices than non-clients, with $95 \%$ of clients engaged in improved health and nutrition practices for their children, as opposed to $72 \%$ for non-clients. Microfinance interventions have also been shown to have a positive impact on the education of clients' children. Again, in the study of FOCCAS, client households were found to be investing more in education than non-client households. Similar findings were seen for projects in Zimbabwe, India, Honduras and Bangladesh.

Chowdhury and Bhuiya (2004, p.377) assessed impact of BRAC's poverty alleviation program from a "human well-being" perspective in a program in Bangladesh where they examined seven dimensions of 'human well-being'. The project included the provision of microfinance and training of Clients on human and legal rights. They noted that the project led to better child survival rates, higher nutritional status, improvement in the basic level of education, and increased networking in the community. Children of BRAC clients suffered from far less protein-energy malnutrition than children of non-members, and the educational performance of BRAC member's children was also higher than that of children in non-BRAC households (ibid.). BRAC member households spent significantly more on consumption of food items than poor non-members did and per capita calorie intake was also significantly higher. Therefore, various studies and findings indicate that microfinance can, and is having very positive and diverse impacts at a beneficiary level.

\subsection{Women Empowerment}

A key objective of many microfinance interventions is to empower women. Mosedale (2003, p.1) states that if we want to see people empowered it means we currently see them as being disempowered, disadvantaged by the way power relations shape their choices, opportunities and well-being. She states that empowerment cannot be bestowed by a third party but must be claimed by those seeking empowerment through an ongoing process of reflection, analysis and action. Women need empowerment as they are constrained by "the norms, beliefs, customs and values through which societies differentiate between women and men". She also states that empowerment refers to the "process by which those who have been denied the ability to make strategic life choices acquire such an ability", where strategic choices are "critical for people to live the lives they want (such as choice of livelihood, whether and who to marry, whether to have children, etc)". Therefore MFIs cannot empower women directly but can help them through training and awareness-raising to challenge the existing norms, cultures and values which place them at a disadvantage in relation to men, and to help them have greater control over resources and their lives. According to Littlefield, Murduch and Hashemi (2003), the Women's Empowerment Program in Nepal found that $68 \%$ of its members were making decisions on buying and selling property, sending their daughters to school and planning their family, all decisions that in the past were made by 
husbands. They refer to studies in Ghana and Bolivia, which indicated that women involved in microfinance projects, had increased self-confidence and had an improved status in the community (ibid.). From studies of the Grameen Bank and BRAC shows that clients of these programs suffered from significantly fewer beatings from their husbands than they did before they joined the MFI (ibid).

\subsection{Socioeconomic Outcomes of Participation in Micro-financed Programs in Bangladesh}

The micro-financed participants borrow money with a great expectation that; from the borrowing they will be able to increase their income and maintain self-employment. Measurement of effects of microfinance programs participants' in terms of consumption, nutrition, employment, net worth, schooling, fertility, etc. can tell the fact whether the borrowers are coming out from poverty or not. In order to assess these effects, impact of the cumulative amount of the participants' borrowing from the MFIs can be considered and thus will reflect both the impact of credit and the duration of the program participation. Moreover, the effects on both male and female borrowers as well as the impact on the local economy also can be measured.

In a specific section we have given a very short description about the evolution of microfinance programs in Bangladesh, which are mainly operated by the three major MFIs; such as: The Grameen Bank (GB), BRAC, and $\mathrm{RD}-12$. In order to demonstrate the overall socioeconomic impacts of microfinance programs, all three MFIs are taken. The Survey Design illustrated by Shahidur R. Khandker (1998) can be described as; the analysis is based on data from a multipurpose household survey conducted in Bangladesh during crop year July 1991 to June 1992, which was undertaken jointly by the BIDS and the World Bank. The main focus of the survey is to provide data for an analysis of three major credit programs (GB, BRAC, and RD-12). The survey covered both program villages of each of these programs and villages in which neither these programs nor any other program providing credit or other activities operated. The survey covered both program target households (those owning no more than half an acre of land) and non-target households (those that did not meet this eligibility criteria) in both program and non-program villages.

Shahidur R. Khandker (1998) demonstrated that participation among target households; less than half (45 percent) of all eligible households participated in micro credit programs (figure .2 (a)).

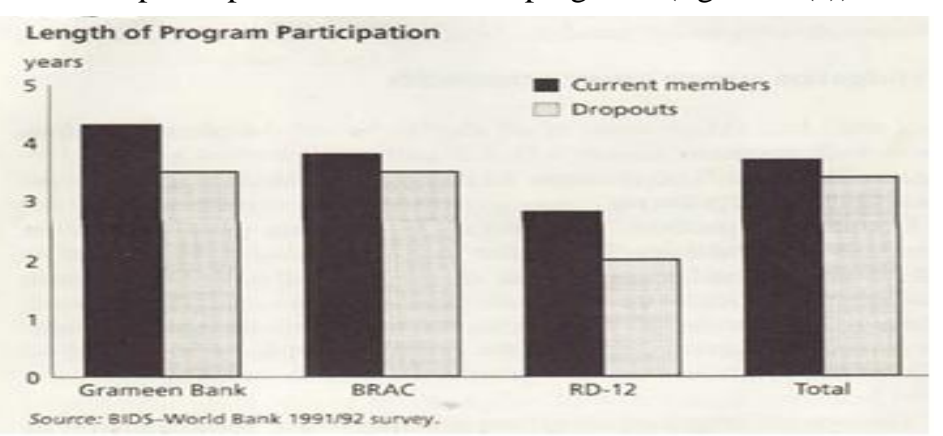

Figure: 2 (a) Program participation among target households

The participation rates were 44 percent in GB villages, 52 percent in BRAC villages, and 33 percent in RD-12 villages. Women represented 76 percent of program participants in GB villages, 73 percent in BRAC villages, 44 percent in RD-12 villages, and 67 percent in all program villages. The dropout rate among participating households was 9 percent in GB villages, 8 percent in BRAC villages, and less than 1 percent in RD-12 villages. Net program participation among target households was 40 percent for GB, 48 percent for BRAC and 33 percent for RD-12. The average length of program participation for current members was 3.7 years for all programs, 4.3 years for GB, 3.8 years for BRAC, and 2.8 years for RD-12 (Figure.2 (b)).Thus GB members on average had more program exposure than members of other programs. Among participants who dropped out, the 
average length of program participation was 3.4 years, and it was higher for GB and BRAC (3.5 years) than RD-12 (2 years).

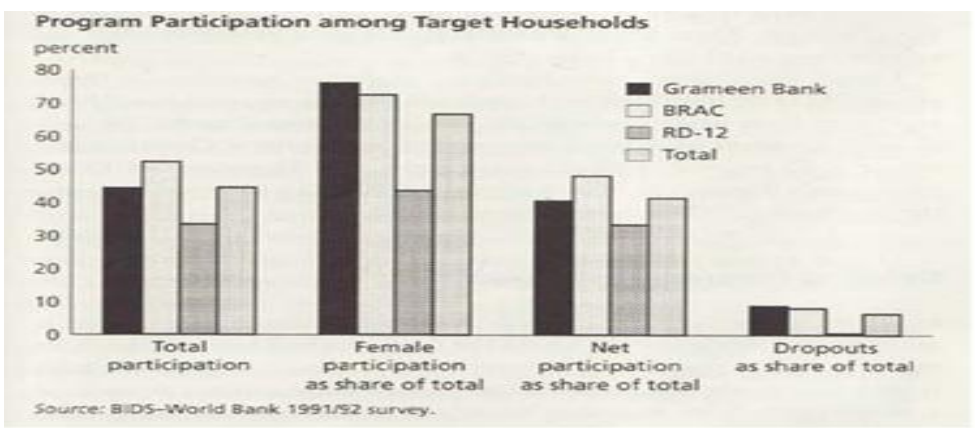

Figure 2 (b) Length of program participation

Concerning the enforcement of eligibility criteria, Shahidur, R. Khandker (1998) illustrates that; Households surveyed were asked about the extent of their land holding before they joined a program. The eligibility criterion was met by 79 percent of households in GB villages, 83 percent in BRAC villages, and 85 percent in RD-12 villages. These findings suggest that these micro credit programs enforce their eligibility criteria tightly. Among participants who met the eligibility criterion, a larger proportion came from landless households (owning no operational holdings) than from landed households (owning no more than half an acre of land). Landless households represented 55 percent of Grameen participants, 65 percent of BRAC participants, and 58 percent of RD-12 participants (figure. 2 (c)). This suggests that BRAC is better at targeting the ultra-poor than GB or $\mathrm{RD}-12$.

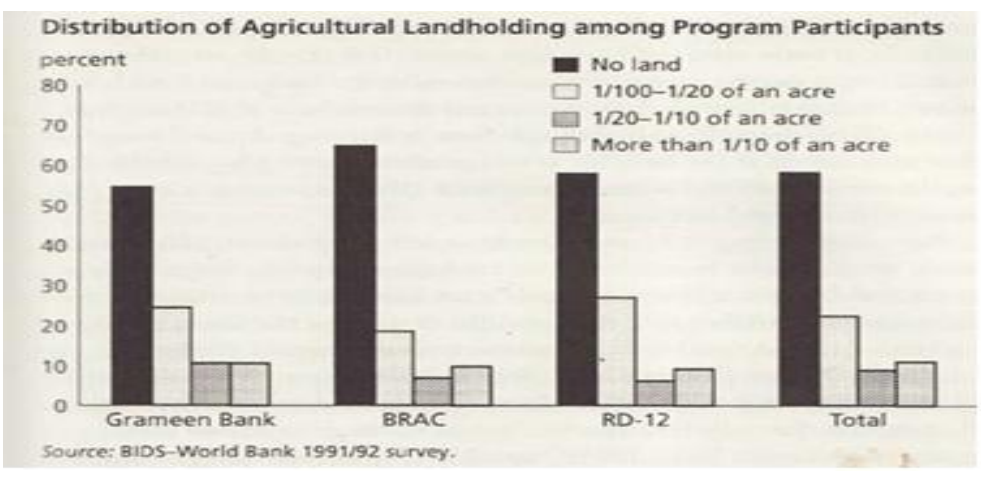

Figure 2(c) Distribution of agricultural landholding among program participants

In order to assess the impact of micro credit programs, some measure of program participation is needed. The measure was estimated using the cumulative amount of borrowing over the five-year period before the survey was conducted and assessed the impact of borrowing on household and individual-level outcomes of interest, including per capita expenditure (food and nonfood), household net worth, women's non land assets, labor supply of men and women, boys' and girls' school enrolment rate, contraceptive use, recent fertility (number of children born in the preceding five years), and nutritional status of children. Furthermore, the measure was also conducted to determine whether micro credit programs can really alleviate the poverty or not, which means the key question arise; does micro credit reduce poverty? In a country such as Bangladesh, poverty can be calculated based on nutritional requirements. According to the FAO, daily consumption of 2112 calories is required to remain above the poverty line. The cost of meeting this requirement can be calculated by pricing various food items and adding a 30 percent allowance to cover the cost of nonfood items (Hossain and Sen 1992). As price differences were observed between villages, the poverty-line level of consumption varied from 
village to village. Village cost of living indices were used to establish TK. 5270 per person per year as the cut-off for moderate poverty. Any household in which per person consumption was less than 80 percent of TK. 5270 (TK. 3330) was defined as living in extreme poverty (see Khandker and Chowdhury 1996). See the following table presents rates of poverty and Net Worth by the borrowers of all three microfinance program participants:

Table 3: Rates of poverty and Net worth accumulation before and after program participation

\begin{tabular}{|c|c|c|c|c|c|c|c|c|}
\hline \multirow{2}{*}{$\begin{array}{l}\text { Poverty } \\
\text { variables } \\
\text { B. prg. }\end{array}$} & \multicolumn{2}{|c|}{ 0-36 months } & \multicolumn{2}{|c|}{ 36-60 months } & \multicolumn{2}{|c|}{$60+$ months } & \multicolumn{2}{|c|}{ Aggregate } \\
\hline & B. prg. & A. prg & B. prg. & A. prg & B. prg. & A. prg. & & A. prg. \\
\hline \multicolumn{9}{|l|}{ Grameen Bank } \\
\hline M.p. (\%) & 89.5 & 80.7 & 86.5 & 62.4 & 75.8 & 51.7 & 82.9 & 61.6 \\
\hline E.p. $(\%)$ & 45.6 & 22.8 & 38.4 & 10.50 & 20.8 & 4.2 & 32.9 & 10.3 \\
\hline H.n.w. (Tk.) & 47.156 & 48.518 & 50.863 & 53.367 & 68.980 & 72.844 & 57.189 & 60.014 \\
\hline P.c.y.con.(Tk.) & 3688 & 4393 & 4043 & 5074 & 4623 & 5672 & 4202 & 5180 \\
\hline H.b. (Tk.) & \multicolumn{2}{|c|}{7,829} & \multicolumn{2}{|c|}{14,391} & \multicolumn{2}{|c|}{22,207} & \multicolumn{2}{|c|}{16,234} \\
\hline \multicolumn{9}{|l|}{ BRAC } \\
\hline M.p. $(\%)$ & 81.8 & 67.0 & 85.5 & 76.3 & 78.3 & 69.2 & 81.3 & 70.4 \\
\hline E.p. $(\%)$ & 38.6 & 13.6 & 31.6 & 13.2 & 32.5 & 14.2 & 34.2 & 13.7 \\
\hline H.n.w. (Tk.) & 64.440 & 65.736 & 67.991 & 69.580 & 63.870 & 66.387 & 65.121 & 67.040 \\
\hline P.c.y.con.(Tk) & 4534 & 5296 & 4183 & 4870 & 4286 & 4984 & 4335 & 5050 \\
\hline H.b. (Tk.) & \multicolumn{2}{|c|}{3,457} & \multicolumn{2}{|c|}{4,236} & \multicolumn{2}{|c|}{6,712} & \multicolumn{2}{|c|}{5,117} \\
\hline \multicolumn{9}{|l|}{ RD-12 } \\
\hline M.p. (\%) & 85.2 & 71.3 & 79.3 & 60.0 & 71.4 & 59.2 & 80.0 & 63.7 \\
\hline E.p. (\%) & 27.7 & 10.9 & 28.7 & 7.3 & 32.7 & 18.2 & 29.0 & 10.3 \\
\hline H.n.w. (Tk.) & 41.270 & 41.770 & 44.843 & 45.493 & 32.482 & 34.111 & 41.633 & 42.380 \\
\hline P.c.y.con.(Tk) & 4253 & 4858 & 4140 & 4827 & 4757 & 5400 & 4279 & 4931 \\
\hline H.b. (Tk.) & \multicolumn{2}{|c|}{4,383} & \multicolumn{2}{|c|}{5,698} & \multicolumn{2}{|c|}{14,294} & \multicolumn{2}{|c|}{6,545} \\
\hline
\end{tabular}

Box 3: Notice box for the table 3

\begin{tabular}{|c|c|c|c|}
\hline \multicolumn{4}{|c|}{$\begin{array}{l}\text { Source of table 3: Shahidur R. Khandker (1998) has calculated from } 1 \\
\text { significance of Various Credit Variables on Socioeconomic Outcomes) } \\
\text { marginal return applies for different durations. } \\
\text { The acronyms \& abbreviations we have used in table } 3 \text { are as follows :- }\end{array}$} \\
\hline $\begin{array}{l}\text { E.p.= Extreme poverty } \\
\text { M.p.=Moderate }\end{array}$ & $\begin{array}{l}\text { B. prg. = Before } \\
\text { program. }\end{array}$ & $\begin{array}{l}\text { H.n.w. = Household net } \\
\text { worth }\end{array}$ & $\begin{array}{l}\text { P. c. y. con.= Per capita } \\
\text { yearly consumption }\end{array}$ \\
\hline & Household & Tk. $=$ Taka & \\
\hline
\end{tabular}

A. prg. = After program borrowing

The calculation of the two measures of poverty- moderate and extreme- are based on per person expenditure for participants before and after program participation (see table 3). About 83 percent of Grameen Bank participants were moderately poor and 33 percent were extremely poor before joining Grameen Bank. After participating in Grameen Bank only 62 percent were moderately poor and only 10 percent were extremely poor. Thus about 21 
percent of Grameen Bank borrowers managed to lift their families out of poverty within 4.2 years of membership. This means that 5 percent of Grameen Bank households rose above poverty each year by borrowing from Grameen Bank. Similarly, 3 percent of BRAC households and 6 percent of RD-12 households rose from poverty each year. Poverty reduction was thus highest for RD-12, followed by Grameen Bank and BRAC, although inter-program differences were not statistically significant. Gains were smallest for RD-12 members who had participated in the program for more than 5 years. However, borrowers who recently joined a micro credit program were poorer than their predecessors, and the gains in poverty reduction were higher among Grameen and BRAC participants with at least 5 years of program experience than among those who recently joined either program. This result suggests that program participation impacts on poverty reduction are likely to be sustainable with micro credit programs. Net worth increased for all programs regardless of participation duration. However, only for Grameen Bank did it increase monotonically as participation duration increased. Impact of microfinance programs at the national level means a lot, since poverty in Bangladesh mainly a matter of challenge for the country, where a large number of the population do not have enough food to eat. Microfinance program is such a weapon that attacks poverty at its sources by increasing the households' consumption expenditure of participants. The survey analysis describes at the national level that; borrowing from a program is estimated to reduce moderate poverty among participants by as much as 20 percent and extreme poverty by as much as 22 percent. This means that as much as 5 percent of program participating households should be able to lift their families out of poverty every year by borrowing from a micro credit program. What does this 5 percent annual poverty reduction for program participants mean at the national level? About half of the poor people in Bangladesh are eligible to participate in micro credit programs. Of those eligible about 45 percent participate. This means that micro credit programs effectively benefit only 20 percent of the population, and about 1 percent of the population $(5 \% * 45 \% * 50 \%)$ can lift itself from poverty each year through such programs (assuming that the number of poor is fixed). But in reality, poor people are growing in Bangladesh rapidly given annual population growth of 1.8 percent per year, which means the total number of poor people in the country will increase in spite of reductions in poverty brought about by micro credit. Microcredit programs also seem to attack poverty on the social front. They empower women and thereby increase their role in household resource allocation, results a direct effect of increasing the welfare of children.

Concerning microfinance programs direct effect on children welfare, I bring one empirical study conducted by Ruhul Amin \&Yiping Li (1997) on "NGO-promoted women's credit programs, immunization coverage, and child mortality in Bangladesh". Their sample of 3564 targeted poor households covered by five NGOs (ASA, RDRS, DCI, CDA, and VERC) in rural Bangladesh. From their study findings it was revealed that, the NGO (collateral free) credit members as well as those who reside in the NGO program area were higher adopters of child immunization than those in the non-program area. Similarly their study found that infant and child mortality was lower among the NGO credit members than among the non-members and that under five year deaths of children progressively decline with the increase in the doses of vaccines. Based on this study finding, in general we can say that the microfinance programs have positive effects on children welfare.

6.8 Achievements of Microfinance in Bangladesh

6.8.1 Achievements of Microfinance in Bangladesh - The Numbers

- More than 1500 MFIs are currently operating, with another many soon to join; $\approx 90 \%$ are clients of 4 big MFIs. Most MFIs consistently report repayment rates of $98 \%+$.

- Microfinance reaches 'significant population of otherwise disadvantaged people'(low/unstable incomes, little/no land/assets, low social status, few/no alternative sources of financial services): 
- $20+$ million active clients ( $\approx 86 \%$ women)

- (under)estimate: $15 \%$ are members of more than one MFI

- (over)estimate: $75 \%$ of clients are poor

- between 10 and 14 million poor households have access to microfinance

6.8.2 Achievements of Microfinance in Bangladesh - Economic and Social Effects

- Evidence is mixed, but on balance suggests 'tangible enhancement of their capabilities', through asset enhancement and positive effects on socio-economic environment:

- On average, positive economic effect on clients (e.g. building non-land assets, consumption smoothing), though effects are often small, and all may not benefit equally

- On average, microfinance and associated MFI activity have had positive social effects(e.g. 'women's empowerment'; education; health; fertility)

- Studies suggest significant village-level spill over effects

\subsubsection{Achievements of Microfinance in Bangladesh - National Level Effects}

- National pride - Bangladesh now renowned for 'invention' of microfinance; commitment and insight of Yunus; vast cadre of competent, honest field staff ... not just poverty, floods etc.; now exports model of microfinance globally(including 'developed' countries).

- Employment creation - at least 50,000 credit officer-type positions across the country whose households derive their livelihood from provision of microfinance.

- Next generation of social entrepreneurs - Microfinance is turning people into social entrepreneurs in different levels especially for new generation.

7. Findings of the Research

- Micro credit contributed to smoothening consumption and reducing vulnerability.

- Wages in Grameen villages and self-employment in off-farm activities increases.

- Microfinance programs have positive effects on children welfare.

- About $68 \%$ of Grameen borrowers' families have crossed the poverty line, the remaining are moving steadily towards the poverty line.

- About 5 percent of Grameen Bank households, 3 percent of BRAC households and 6 percent of RD-12 households rose above poverty each year by borrowing.

- Positive impact on children's schooling: A 1.5\% increase in Grameen Bank female borrowers increases the probability of school enroll $2.5 \%$ for boys.

- Marginal propensity to consumption increased (18\% for women; $11 \%$ for male borrowers).

- About 5.5\% of Grameen Bank and 2.99\% of BRAC households rose to poverty level.

- Household income increase by $31 \%$ and $35 \%$ for Grameen Bank and BRAC borrowers respectively.

- $10 \%$ increase in BRAC credit increased household net worth by $0.09 \%$ and $0.14 \%$ for female borrowers.

8. Recommendation of the Research

- Ensuring Participation in Microcredit Program: Impacts of microcredit program participation in order to poverty reduction are likely to be sustainable with micro credit programs. Net worth increased for all programs regardless of participation duration. Impact of microfinance programs at the national level means a lot, since poverty in Bangladesh mainly a matter of challenge for the country, where a large number of the population do not have enough food to eat. Microfinance program is such a weapon that attacks poverty at its sources by increasing the households' consumption expenditure of participants. 
- Selecting Target Group: Both men and women should be targeted equally especially in family planning programs in order to obtain maximum impact from microfinance.

- Creating Environment To Invest Remittances in Capital Market: Since remittances play a significant role for the balance of payment as well as economic development of the country, the government can make easy access to the capital market for the remittance recipient families. Moreover, Bangladesh is role model and considered as pioneer in Microfinance. Many Microfinance Institutes (MFIs) and Non-Government Organizations (NGOs) are operating in Bangladesh. But still this remittance sector is untapped by them. Although at present there is a provision for quota of foreign investors or nonresident Bangladeshis' during Initial Public Offering (IPO) of issuing shares, but this process is so critical that most of the time this quota doesn't fulfilled. The government should make this quota system of issuing IPO also applicable for the families of the non-resident Bangladeshis, so that they can invest in the capital market.

- Utilization of Remittances in Productive Investment: The government as well as private sectors specially the MFIs/NGOs can come forward in this regard. At present one NGO is playing role of transferring remittances. But the MFIs/NGOs need to do more beyond transfer. The government should eliminate regulatory constraint of transferring remittance for MFIs/NGOs. The government as well as MFIs/NGOs can provide Business Development Services to the remittances recipient families to start and operate an enterprise. If the government makes the regulation flexible regarding savings and credit products of MFIs/NGOs, then the MFIs/NGOs can develop appropriate savings, credit and insurance products for remittance recipient families. The Government can also establish Investment Company to channel more capital through MFIs/NGOs to the remittance recipient families which are operating enterprise.

- Develop New Foreign Policy: The government should develop new foreign policy and assigned a professional person at each diplomatic mission office abroad to explore the potentials of manpower export in that country and properly lobby with different concerned persons of that country. At present although the government has a post of labor attaché in diplomatic mission of some countries, but still it is insignificant.

\section{Conclusion}

Microfinance service provides credit to the poor without collateral. Yunus's Grameen Model is one of the best ways to transfer the microfinance services into a social mechanism system which ultimately streamline the poor people into the socioeconomic development of the country and which are the reflections of today's Bangladesh in the world. Microfinance services help the poor people not only to survive but also make them productive, self-employed. Microfinance service has much contribution to Bangladesh's key economic development indicators, because it helps to increase GDP, GNP, Savings, etc. Penniless people who did not have any collateral are becoming self-employed by getting microfinance services. Microfinance reduces poverty by increasing per capita consumption among program participants and their families. As a result, the poor are coming above the Poverty Line and eventually help to increase the GDP, savings, etc. accordingly. Microfinance plays a very important role for rural women's empowerment perspectives, because women have clearly benefited by getting access to the credit; they are able to increase their income generating activities, become owner of non-land assets, etc. As a result these influence their children's consumption, schooling and thus independent effect on household resource allocation. So, the vision of microfinance in Bangladesh is explicit, that is; not only alleviate the poverty but also play as a vital socioeconomic development mechanism. Through 
the microfinance program participation, the poor can be covered by savings mobilization and sustainable credit market. It is such an instrument which is capable to eradicate the poverty from the below and eventually it helps to maintain a peaceful society.

\section{References}

Chowdhury MR, Mosley P, Simanowitz A. (2004).The social impact of microfinance. Journal of International Development, 16, 291-300.

Chowdhury, A. \& Abbas Bhuiya, (2002). The Wider Impacts of BRAC Poverty Alleviation Programme, Impact Programme Document,15, 13-14.

Carney, D.(1998).Sustainable Rural Livelihoods: What contribution can we make? London: Department for International Development.

Dichter, T.W. (1999). NGOs in Microinance: Past, Present and the Future. In Breth, S.A. (Ed.) Microinance in Africa., Sasakawa Africa Association, Mexico City.

Hossain, Mahabub and Binayek Sen.(1992). Rural poverty in Bangladesh: trends and determinants. Asian Development Review ,10(1),1-34.

Hulme, D., \& Mosley, P. (1997). Finance for the poor or Poorest? Financial Innovation, Poverty and Vulnerability. Dhaka: The University Press.

Kabeer, N. (2003). Assessing the "Wider" Social Impacts of Microinance Services: Concepts, Methods, Findings. IDS Bulletin, 34(4), 106- 114.

Khandker, Shahidur R.(1998). Fighting Poverty with Microcredit: Experience in Bangladesh. New York: Oxford University Press.

Ledgerwood, J. (1999). Microfinance Handbook. Sustainable Banking with the Poor. An Institutional and Financial Perspective, The World Bank, Washington D.C.

Littleield, E., Murduch, J. and Hashemi, S. (2003). Is Microfinance an Effective Strategy to Reach the Millennium Development Goals, CGAP, Focus Note 24.

Littlefield \& Rosenberg.(1996).The role of Rural Credit Projects in Reaching the Poor: IFADs experience. In ILO (ed) Group Based Savings and Credit of the Rural Poor, Geneva.

Morduch, J., \& Haley, B. (2002). Analysis of the Effects of Microfinance on Poverty Reduction. New York: NYU Wagner Working Papers Series.

Navajas, S., Schreiner, M., Gonzalez-Vega, C. and Rodriguez-Meza, J. (2000). Microcredit and the Poorest of the Poor: Theory and Evidence from Bolivia. World Development, 28(2), 333-346.

Otero, M. (1999). Bringing Development Back into Microfinance. Journal of Microfinance, 1(1), 8-19.

Robinson, Marguerite. (2001). The Microfinance Revolution: Sustainable finance for the poor. Washington, DC: The World Bank, 304.

Robinson, M. S. (2001). The Microfinance Revolution: Sustainable Finance for the Poor. Washington D.C.: The World Bank.

Rogaly, B. (1996). Micro-Finance Evangelism, Destitute Women, and the Hard Selling of a New Anti Poverty Formula. Development in Practice,6(2),100-112.

Schreiner, M. and Colombet, H.H. (2001) From Urban to Rural: Lessons for Microfinance from Argentina. Development Policy Review. 19(3), 339-354.

Shahidur R. Khandker .(1998). The Impact of Group-Based Credit Programs on Poor Households in Bangladesh: Does the Gender of Participants Matter?. Journal of Political Economy, 106, 958-96.

Simanowits, W\& Brody, F .(2004). 'International Finance Corporation.Emerging Stock Markets' Fact Book, 
Washington DC.

Sinha, S.(1998). Microcredit: Introduction and review. IDS Bulletin,29(4),1-9.

UNCDF .(2004). Basic Facts about Microfinance, [Online]. Available from [23rd August 2004].

Wright, G. (2000). Microfinance Systems: Designing Quality Financial Services for the Poor. London/Dhaka: Zed Books/University Press.

Copyrights

Copyright for this article is retained by the author(s), with first publication rights granted to the journal. 